\title{
Evaluation of Ash Pozzolanic Activity by Means of the Strength Activity Index Test, Frattini Test and DTA/TG Analysis
}

\author{
Sabina KRAMAR, Vilma DUCMAN
}

\begin{abstract}
The pozzolanic activity of five different types of ash was studied using various direct and indirect methods. In addition to strength activity index (SAI) determination and the Frattini test, ash pozzolanicity was assessed via differential thermal and thermogravimetric analyses (DTA/TG) after curing for 7, 28 and 90 days. The results showed that, due to their respective mineralogical, chemical and physical characteristics, the ashes exhibited different levels of pozzolanic activity in terms of the amount of lime with which they could chemically bind, as well as reaction kinetics. Although SAI and Frattini test results were not in agreement in the case of some of the ashes, DTA/TG analysis revealed that a certain amount of portlandite was consumed, thus confirming the occurrence of a pozzolanic reaction. The results also showed that ashes with higher amounts of reactive $\mathrm{SiO}_{2}$ were more reactive, while those with higher $\mathrm{BET}$ surface areas displayed a faster pozzolanic reaction rate.
\end{abstract}

Keywords: biomass ash, DTA/TG, fly ash, Frattini test, pozzolanic activity, SAI

\section{INTRODUCTION}

Supplementary cementitious materials (SCMs), including fly ash, ground granulated blast furnace slag, silica fume, calcined clays and natural pozzolans, are increasingly used in the construction sector, e.g. as mineral additives in blended cements and concrete mixtures, or as precursors for alkali-activated materials, a pattern that is driven by both economic and environmental incentives. The majority of modern cements contain either one or more types of SCM, some of which are industrial by-products, most commonly fly ashes or slag [1]. However, global supplies of SCMs are limited compared to the amount of clinker produced, while a very high proportion of suitable SCMs is already used in blended cements [2]. Furthermore, variability in SCM properties and quality is far larger than that of Portland cement [3]. Therefore, most recent research has focussed on the exploration of alternative SCMs and their performance in building materials [1]. In this regard, identifying materials from new sources, maximising their use and improving their performance can be best achieved through appropriate characterisation and assessment of pozzolanic reactivity.

Among SCMs, fly ash is by far the most widely used to increase average levels of clinker substitution and in the manufacture of concrete products due to its low cost, availability and property-enhancing characteristics. Current standards (EN-197-1 [4], EN 450-1 [5]) allow the use of fly ash from power stations, which originates from the combustion of coal with or without co-combustion of biomass materials or other sources. However, the amount of ash derived from co-combustion must not exceed $30 \%$ by mass of the total ash. Ashes of other origin, such as municipal and industrial waste incineration ashes [6], are excluded from addition to cements or concrete. When used as a pozzolanic material, fly ash contributes to the improvement of binder properties due to its capacity to react with the $\mathrm{Ca}(\mathrm{OH})_{2}$ generated by cement hydration. This results in the production of hydrates that are similar to those of hydrated cement, which are responsible for the development of mechanical resistance, as well as contributing to the densification of the matrix binder, sealing pores and reducing vulnerability to external agents
[7]. The utilisation potential of fly ash is mainly controlled by its chemical composition, but also by particle size, amorphous phase content, specific surface area, morphology and surface texture [8-10]. In contrast to those obtained from coal combustion, biomass fly ashes are characterised by a high content of calcium oxide, silica and alumina, and a low content of iron oxide [11]. Although biomass-combustion fly ashes are today typically disposed of in landfills or recycled on agricultural fields and forest land [11], they do, similarly to coal-combustion fly ashes, possess a certain capacity to react chemically with $\mathrm{Ca}(\mathrm{OH})_{2}$, producing a relatively stable C-S-H gel $[12,13]$.

Many different methods involving various chemical or physical tests can be used for the assessment of SCM pozzolanic activity [2, 3, 14-19]. Pozzolanic activity is characterised by two parameters: the maximum amount of lime with which the pozzolan can chemically bind, and the rate at which such a reaction takes place [20]. Whereas the overall amount of combined lime depends mainly on the nature, quality and quantity of active phases present in the pozzolan, the lime combination rate varies with the particle size and specific surface area of the pozzolan, the water/solid ratio and the curing temperature [20,21]. While it is common for pozzolanic activity to be investigated using more than one method, at least one of these methods is likely to be qualitative, with most studies involving a combination of direct and indirect methods to measure the consumption of portlandite over time [22]. However, inconsistencies may arise when the activity of materials of different origin is compared, as SCM reactivity is dependent on several factors [3] that vary in their correlation [22]. Within the scope of the present study, three different methods were applied for the assessment of pozzolan activity: the strength activity index (SAI) according to EN 450-1 [5], the Frattini test following the procedure of EN 196-5 [23], and differential thermal analysis and thermogravimetry (DTA/TG) [24]. The SAI test is an indirect method in which the measured compressive strength of ordinary Portland cement CEM I is compared to that of a mixture, where $25 \%$ of the former is replaced by the tested pozzolan. In contrast, the Frattini test and DTA/TG are direct methods, since they involve direct measurements of the amount of $\mathrm{Ca}(\mathrm{OH})_{2}$ that is 
spent in the reaction. The Frattini test method is based on chemical titration, and is used to determine the amount of dissolved $\mathrm{Ca}^{2+}$ and the $\mathrm{OH}^{-}$concentrations in a solution containing the tested pozzolan. DTA/TG is widely preferred for the characterisation of pozzolanic activity since it measures the reduction of $\mathrm{Ca}(\mathrm{OH})_{2}$, which reflects the pozzolanic action of the admixture as a function of the percentage used and time from the beginning of the hydration process [25]. Several studies have found that the $\mathrm{Ca}(\mathrm{OH})_{2}$ consumption that takes place in lime/pozzolan pastes could be a reliable indicator of pozzolanic reactivity [17, 25-27].

In the present work the pozzolanic activity of five ashes originating from various sources was investigated in order to verify the possible use of these by-products in building materials. The main chemical and physical parameters as well as the phase composition of the ashes were determined, with pozzolanic activity analysed using the strength activity index test, the Frattini test and DTA/TG analysis.

\section{EXPERIMENTAL}

\subsection{Materials}

Five ashes originating from different sources were investigated, including two types of fly ash (K2, K3) originating from coal thermal power plants, and one (K1) derived from the co-combustion of coal and biomass material at a heat and power station. The final two types of ash were obtained from a paper mill, with ash K4 representing fly ash from the combustion of coal, biomass and/or paper sludge, and $\mathrm{K} 5$ the combustion residue from a steam boiler in which de-inking fibre paper sludge, waste wood and bark are used as fuel, producing a mixture of ca. $90 \%$ bottom ash and $10 \%$ fly ash.

\subsection{Methods}

The phase compositions of the ash samples were determined via X-ray diffraction in a Philips PW3710 Xray diffractometer equipped with $\mathrm{CuK} \alpha$ radiation with $\lambda=1.54060 \AA \AA n m$, a secondary graphite monochromator and a proportional counter. Data were collected at $40 \mathrm{kV}$ and a current of $30 \mathrm{~mA}$, over the $2 \theta$ range from 4 to $70^{\circ}$ at a scan rate of $1.2^{\circ} 2 \theta / \mathrm{min}$. Samples were milled to a particle size of less than $50 \mu \mathrm{m}$. The crystalline standard used to prepare the binary mixtures was alumina powder (SRM 676aNIST), with the ash samples and standard mixed together in a ratio of 90/10. All Rietveld refinements with pseudoVoigt function and a polynomial background were performed using the X'PertHighScore Plus diffraction software from Panalytical with PAN-ICSD (PW3213) powder diffraction files.

The chemical compositions of the ashes were determined using a Thermo Scientific ARL PERFORM'X Wavelength Dispersive X-Ray Fluorescence Spectrometer (WDXRF) with a Rh-target X-ray tube and the UniQuant program. Prior to the measurements, samples were dried at $105^{\circ} \mathrm{C}$ and heated at $950{ }^{\circ} \mathrm{C}$; a fused bead was then prepared with lithium tetraborate $50 \%$ /lithium metaborate $50 \%$, with a 1:10 mixture of the ash and flux heated at 1025 ${ }^{\circ} \mathrm{C}$. Ash sulphate content and loss on ignition (LOI) were determined in accordance with EN 196-2 [28], and the content of free calcium oxide $(\mathrm{f}-\mathrm{CaO})$ and contents of reactive calcium oxide $(\mathrm{CaO})$ and reactive silicon dioxide $\left(\mathrm{SiO}_{2}\right)$ determined according to EN 451-1 [29] and EN 197-1 [4], respectively.

The total specific area or Brunauer-Emmet-Teller (BET) surface area of the samples was determined via nitrogen adsorption at $77 \mathrm{~K}$ over a relative pressure range of 0.05 to 0.3 using a Micromeritics ASAP 2020 instrument. Prior to the measurements, the samples were dried at $105{ }^{\circ} \mathrm{C}$, outgassed at a heating rate of $10{ }^{\circ} \mathrm{C} / \mathrm{min}$ up to $70{ }^{\circ} \mathrm{C}$ and evacuated at $70{ }^{\circ} \mathrm{C}$ at an evacuation rate of $1.33 \mathrm{kPa} / \mathrm{s}$, until a final vacuum of $1.3 \mathrm{~Pa}$ was achieved. In addition, the fineness of the ashes, as the amount of ash retained when sieved through a $0.045 \mathrm{~mm}$ mesh sieve, was determined via wet sieving in accordance with EN 451-2 [30].

Strength activity index (SAI) values of the studied ashes were determined according to EN 450-1 [5]. Mortar mixtures with $25 \%$ cement replacement by ash were prepared and tested according to EN 196-1 [31], with a water to binder ratio of 0.5 and a binder to aggregate ratio of $1: 3$. According to the aforementioned standard, the activity index, defined as the ratio of the compressive strength of mortar containing $25 \%$ ash as an SCM to that of a control mortar, should not be less than $75 \%$ and $85 \%$ after 28 days and 90 days, respectively.

For the Frattini pozzolanicity test, $20 \mathrm{~g}$ samples consisting of $80 \%$ CEM I and $20 \%$ ash were prepared and mixed with $100 \mathrm{ml}$ distilled water [22]. The test was carried out according to the procedure described in standard EN 196-5 [23], with the ashes ground to pass through a $125 \mu \mathrm{m}$ sieve. This test involves the determination of the amount of $\left[\mathrm{Ca}^{2+}\right]$ (expressed as equivalent $[\mathrm{CaO}]$ ) and $\left[\mathrm{OH}^{-}\right]$in the aqueous solution in contact with the tested samples, stored at $40{ }^{\circ} \mathrm{C}$ until the testing period. The test is considered positive for a pozzolanic addition when, at 8 or 15 days, the $\left[\mathrm{Ca}^{2+}\right]$ and $\left[\mathrm{OH}^{-}\right]$concentrations in the sample solution are below the isotherm of calcium hydroxide solubility in an alkaline solution at $40^{\circ} \mathrm{C}$.

Ash pozzolanic activity was also assessed via DTA/TG after curing for 7, 28 and 90 days. The lime/ash mixtures $(20 \mathrm{~g})$ were prepared by mixing $70 \%$ ash and $30 \%$ $\mathrm{Ca}(\mathrm{OH})_{2}$, by weight [24]. The pastes, which were prepared at equivalent consistencies according to EN 196-1 [31], were enclosed in hermetically sealed plastic bags and stored at room temperature for the given period of time. The water/binder ratios of the lime/ash mixtures at standard consistency were as follows: $\mathrm{K} 1: 0.50, \mathrm{~K} 2: 0.41$, K3: 0.35 , K4: 0.60 and K5: 0.81. At testing, the samples were removed from the plastic bags and the hydration process inhibited by means of isopropanol (samples were placed for $0.5 \mathrm{~h}$ in isopropanol and then dried at $70{ }^{\circ} \mathrm{C}$ for $0.5 \mathrm{~h}$ ). The samples were then subjected to the DTG/TG analyses. Thermogravimetric (TG) measurements were performed on a Netzsch STA 409 instrument from room temperature up to $1000^{\circ} \mathrm{C}$, at a heating rate of $10^{\circ} \mathrm{C} / \mathrm{min}$. Samples with an initial mass of approx. $50 \mathrm{mg}$ were placed in $\mathrm{Al}_{2} \mathrm{O}_{3}$ crucibles. During the measurements, the furnace was purged by means of synthetic air flow at a rate of 20 $\mathrm{mL} / \mathrm{min}$. Differential thermal analysis (DTA) measurements were performed simultaneously on the Netzsch STA 409 instrument, with the results analysed using the Netzsch Proteus Thermal Analysis software. The 
residual portlandite content of the lime/ash pastes after each testing period was measured via thermogravimetric analysis (TGA) from the weight loss over the portlandite $\mathrm{Ca}(\mathrm{OH})_{2}$ dehydroxilation interval and compared to that of paste containing $30 \%$ lime and $70 \%$ quartz powder.

\section{RESULTS AND DISCUSSION \\ 3.1 Characterisation of Ashes \\ 3.1.1 Phase Composition}

X-ray powder diffraction (Tab. 1) revealed the variable phase composition of the studied ashes. The main reactive component of all samples was an amorphous phase, the proportion of which was highest in coal fly ash K3 (84\%) and lowest in mixed ash K5 (44\%). Quartz and periclase were present in different amounts in all samples. Whereas hematite was found in all samples with the exception of ash $\mathrm{K} 5$, lime was recorded in all but fly ash $\mathrm{K} 3$, and was especially abundant in ash K5. Brownmillerite, a hydraulic phase, was present in the two ashes derived from the cocombustion of coal and biomass (K1, K4), whereas gehlenite, which has poor hydraulic properties, was identified in ashes $\mathrm{K} 1, \mathrm{~K} 2$ and $\mathrm{K} 4$. Additional phases included mullite (K3), anhydrite (K2), plagioclases (K2) and calcite (K3, K4, K5). The last was especially enhanced in ash K5, together with portlandite and the hydraulic phases larnite and mayenite.

Table 1 Quantitative phase composition of the studied ashes, determined via

\begin{tabular}{|l|c|c|c|c|c|}
\hline Phase (wt. \%) & K1 & K2 & K3 & K4 & K5 \\
\hline Amorphous & 71,7 & 70,0 & 84,4 & 72,1 & 44,3 \\
\hline Anhydrite & - & 3,7 & - & - & - \\
\hline Brownmillerite & 5,8 & - & - & 3,3 & - \\
\hline Calcite & - & - & 0,3 & 0,5 & 25,8 \\
\hline Gehlenite & 0,6 & 5,2 & - & 3,2 & - \\
\hline Hematite & 7,7 & 7,4 & 1,5 & 3,3 & - \\
\hline Larnite & - & - & - & - & 10,0 \\
\hline Lime & 2,3 & 2,1 & - & 0,7 & 6,2 \\
\hline Mayenite & - & - & - & - & 4,2 \\
\hline Mullite & - & - & 7,3 & - & - \\
\hline Periclase & 4,9 & 2,1 & 0,9 & 4,3 & 1,0 \\
\hline Plagioclase & - & 5,5 & - & - & - \\
\hline Portlandite & - & - & - & - & 5,4 \\
\hline Quartz & 7,1 & 4,1 & 5,6 & 12,7 & 3,0 \\
\hline
\end{tabular}

\subsubsection{Chemical Composition and Physical Characteristics}

As can be seen from Tab. 2, ash $\mathrm{SiO}_{2}$ content ranged from 12.61 to $51.77 \%$, the lowest value being obtained for ash $\mathrm{K} 5$ and the highest for $\mathrm{K} 3$. Ash reactive $\mathrm{SiO}_{2}$ content ranged from 12.0 to $38.2 \%$, showing that a large proportion of the $\mathrm{SiO}_{2}$ present is reactive in fly ashes $\mathrm{K} 2$ and $\mathrm{K} 3$, both of which originated from coal combustion. It is interesting to note that despite the rather high $\mathrm{SiO}_{2}$ content of ashes $\mathrm{K} 1$ and $\mathrm{K} 4$, only about half was determined as reactive. This is likely related to the amorphous phase and, to a minor extent, other reactive phases present in these two samples, such as brownmillerite and gehlenite. Moreover, ashes $\mathrm{K} 1$ and $\mathrm{K} 4$ also contained enhanced levels of nonreactive phase quartz. In contrast, although in ash $\mathrm{K} 5$ almost all $\mathrm{SiO}_{2}$ was reactive, the total amount was rather low, which is apart from the amorphous phase linked to the presence of reactive phase larnite, as well as a small amount of quartz. Ash $\mathrm{CaO}$ levels were within the range of 6.01 to $52.17 \%$, with the smallest amount recorded in ash
$\mathrm{K} 3$ and the highest in $\mathrm{K} 5$. These values largely relate to the relative content of $\mathrm{Ca}$-based minerals, with higher amounts of calcite, lime and portlandite found in ash K5. According to standard EN 197-1 [4], coal fly ash K3 can be classified as a siliceous fly ash $(<10 \% \mathrm{CaO})$ and $\mathrm{K} 2$ as a calcareous fly ash $(>10 \% \mathrm{CaO})$. Ash $\mathrm{K} 5$ also exhibited the highest $\mathrm{f}$ $\mathrm{CaO}$ content at $14.2 \%$, with the remaining four ashes falling within the range from 0.5 to $3.4 \%$. The amount of reactive $\mathrm{CaO}$ ranged from $4.8 \%$ to $23.0 \%$, with levels in ash $\mathrm{K} 5$ related mainly to the reactive phase larnite. $\mathrm{Fe}_{2} \mathrm{O}_{3}$ and $\mathrm{Al}_{2} \mathrm{O}_{3}$ contents ranged from $0.47 \%$ to $17.24 \%$ and from $8.81 \%$ to $22.96 \%$, respectively. The highest $\mathrm{Fe}_{2} \mathrm{O}_{3}$ concentrations were observed in ash $\mathrm{K} 1$, followed by $\mathrm{K} 2$, $\mathrm{K} 3$ and K4, likely due to the presence of hematite and brownmillerite in these samples. Reflecting its low content of amorphous phase as well as of other Al-bearing minerals, ash $\mathrm{K} 5$ contained the smallest amount of $\mathrm{Al}_{2} \mathrm{O}_{3}$. $\mathrm{MgO}$ concentrations ranged between $2.17 \%$ and $10.58 \%$, with the highest values detected in ash $\mathrm{K} 1$, possibly related to the presence of periclase. Alkali levels ranged from $0.99 \%$ to $2.20 \%$ for $\mathrm{K}_{2} \mathrm{O}$ and from $0.17 \%$ to $0.79 \%$ for $\mathrm{Na}_{2} \mathrm{O}$, suggesting a rather low total alkali content that was greatest in the two coal fly ashes (K2, K3). The $\mathrm{SO}_{3}$ content of the studied ashes ranged from $0.55 \%$ to $2.73 \%$, being especially enhanced in samples $\mathrm{K} 1$ and $\mathrm{K} 2$, while $\mathrm{P}_{2} \mathrm{O}_{3}$ levels ranged up to $0.40 \%$.

LOI values, mainly attributed to the presence of organic matter and carbonates, varied from $2.30 \%$ to $21.79 \%$, and were significantly higher in the two ashes obtained from the paper mill (K4, K5).

Table 2 Chemical and physical characteristics of the studied ashes

\begin{tabular}{|c|c|c|c|c|c|c|}
\hline & $\mathrm{K} 1$ & $\mathrm{~K} 2$ & $\mathrm{~K} 3$ & K4 & K5 & $\begin{array}{c}\text { EN 450-1 } \\
\text { req. }\end{array}$ \\
\hline \multicolumn{7}{|c|}{ Chemical composition (\%) } \\
\hline $\mathrm{SiO}_{2}$ & 26,11 & 39,37 & 51,77 & 37,46 & 12,61 & \multirow{3}{*}{$>70,0 \%$} \\
\hline $\mathrm{Al}_{2} \mathrm{O}_{3}$ & 10,57 & 17,01 & 22,96 & 13,02 & 8,81 & \\
\hline $\mathrm{Fe}_{2} \mathrm{O}_{3}$ & 17,24 & 8,62 & 7,36 & 6,77 & 0,47 & \\
\hline $\mathrm{CaO}$ & 20,30 & 18,63 & 6,01 & 12,04 & 52,17 & \\
\hline $\mathrm{P}_{2} \mathrm{O}_{5}$ & 0,14 & 0,40 & b.d.l. & 0,25 & 0,20 & $<5 \%$ \\
\hline $\mathrm{MgO}$ & 10,58 & 3,92 & 2,45 & 3,65 & 2,17 & $<4 \%$ \\
\hline $\mathrm{K}_{2} \mathrm{O}$ & 0,99 & 1,79 & 2,20 & 0,84 & 0,24 & \\
\hline $\mathrm{Na}_{2} \mathrm{O}$ & 0,18 & 0,78 & 0,79 & 0,31 & 0,17 & \\
\hline $\mathrm{SO}_{3}$ & 2,11 & 2,73 & 0,73 & 1,28 & 0,55 & $<3 \%$ \\
\hline LOI & 10,17 & 5,01 & 2,30 & 21,79 & 20,42 & $<9 \%$ \\
\hline Free $\mathrm{CaO}$ & 2,7 & 3,4 & 0,5 & 0,9 & 14,2 & $<1,5 \%$ \\
\hline Reactive $\mathrm{CaO}$ & 17,0 & 17,7 & 4,8 & 9,3 & 23,0 & $<10,0 \%$ \\
\hline Reactive $\mathrm{SiO}_{2}$ & 15,1 & 34,0 & 38,2 & 22,0 & 12,0 & $>25 \%$ \\
\hline \multicolumn{7}{|c|}{ Physical properties } \\
\hline $\begin{array}{c}\text { BET surface } \\
\text { area }\left(\mathrm{m}^{2} / \mathrm{g}\right)\end{array}$ & 33,4 & 16,7 & 1,7 & 66,4 & 7,4 & \\
\hline $\begin{array}{c}\text { Fineness } \\
\text { (\% of particles } \\
>45 \mu \mathrm{m})\end{array}$ & 24,5 & 37,9 & 19,0 & 42,0 & 59,6 & $<40 \%$ \\
\hline
\end{tabular}

Regarding their physical parameters, the studied ashes differed significantly in terms of both fineness and BET surface area. Values of the latter ranged from $1.7 \mathrm{~m}^{2} / \mathrm{g}$ to $66.4 \mathrm{~m}^{2} / \mathrm{g}$, with the highest BET surface area observed for ash K4. Ash fineness ranged from $19.0 \%$ for ash K3 to $59.6 \%$ for ash $\mathrm{K} 5$, indicating a high and low amount of fine particles $(<45 \mu \mathrm{m})$, respectively.

According to EN 450-1 [5], the sum of $\mathrm{SiO}_{2}, \mathrm{Al}_{2} \mathrm{O}_{3}$ and $\mathrm{Fe}_{2} \mathrm{O}_{3}$ should not be less than $70 \%$, a requirement here fulfilled only by the siliceous fly ash K3. In contrast, the sulphate content of the studied ashes was, in all cases, 
below the limit $(<3 \%)$ required by this standard, as was the total content of alkalis $\left(\mathrm{Na}_{2} \mathrm{O}_{\mathrm{eq}}<5 \%\right)$ and phosphate $(<5 \%)$. However, in the case of ash $\mathrm{K} 1$, which originated from the co-combustion of coal and biomass, $\mathrm{MgO}$ content exceeded the permitted limit of $4 \%$. LOI $(<9 \%)$ and reactive $\mathrm{SiO}_{2}(>25 \%)$ requirements were met only by the calcareous (K2) and siliceous (K3) fly ashes, while ashes $\mathrm{K} 3$ and $\mathrm{K} 4$ fulfilled the criteria for $\mathrm{f}-\mathrm{CaO}(<1.5 \%)$ and reactive $\mathrm{CaO}(<10 \%)$. All ashes with the exception of the two obtained from the paper mill (K4, K5) met the requirements for fineness $(<40 \%)$.

\subsection{Pozzolanic Activity 3.2.1 Strength Activity Index}

The strength activity index (SAI) values of the studied ashes are presented in Fig. 1. It can be seen from this figure that fly ashes $\mathrm{K} 1, \mathrm{~K} 2$ and $\mathrm{K} 3$ met SAI requirements after 28 days, achieving values greater than $75 \%$, with the highest obtained for the siliceous fly ash (K3). After 90 days SAI values had increased further; those for the two fly ashes from coal thermal power plants (K2 and K3) were higher than the limit indicating sufficient activity $(\geq 85 \%)$, with that obtained for the fly ash from the heat and power station (K1) slightly below this limit. It can also be observed that, after 90 days, whereas index value increased only slightly in the case of fly ash $\mathrm{K} 1$, a significant increase was recorded in the case of ash $\mathrm{K} 3$, indicating significant progress of the pozzolanic reaction. In contrast, the two ashes from the paper mill (K4, K5) exhibited activity index values below the required limits, both after 28 and 90 days. In addition, the values obtained for these two ashes did not change significantly after 90 days. Overall, the compressive strength contribution of the ashes followed the order $\mathrm{K} 3>\mathrm{K} 2>\mathrm{K} 1>\mathrm{K} 5>\mathrm{K} 4$.

According to the above SAI results, sufficient strength activity developed in the fly ashes containing high levels of reactive $\mathrm{SiO}_{2}$ (ashes K2 and K3). Siliceous fly ash K3 presented considerable pozzolanic activity, with its content of the amorphous phase, reactive $\mathrm{SiO}_{2}$, as well as $\mathrm{Al}_{2} \mathrm{O}_{2}$ content and share of fine particles the highest among all samples. In contrast, whereas fly ash $\mathrm{K} 1$ exhibited almost sufficient SAI values despite its low content of reactive $\mathrm{SiO}_{2}$, the two ashes obtained from the paper mill (K4, K5), which contained similarly low levels of reactive $\mathrm{SiO}_{2}$, presented SAI values far below the limit. Importantly, the two fly ashes that showed early reactivity contained high amounts of reactive $\mathrm{CaO}$, which likely contributed to this strength development [32]. Siliceous fly ashes are pozzolanic in nature, while calcareous fly ashes react both pozzolanically and hydraulically. Ashes K4 and K1, which both originated from the co-combustion of coal and biomass, contained similar proportions of the amorphous phase. However, these two ashes showed different amounts of fine particles, with the higher content in $\mathrm{K} 1$ contributing to the latter's higher SAI values [33], despite its lower reactive $\mathrm{SiO}_{2}$ content. Moreover, as ash K4 exhibited greater water demand due to its high BET surface area, the fact that the w/c ratio was kept constant for all materials during the SAI test could have prevented the occurrence of hydration reactions, due to water insufficiency. Ash K5 presented inadequate SAI values as a result of its low amorphous phase content, as well as a rather large proportion of other non-reactive phases and consequently small amount of reactive $\mathrm{SiO}_{2}$. This ash also contained the greatest relative proportion of particles $>45 \mu \mathrm{m}$ among all tested samples, as well as high water demand. Thus, the difference in the BET surface area, which was much lower in fly ash $\mathrm{K} 3$, most probably contributed to the slower reactivity of the latter sample.

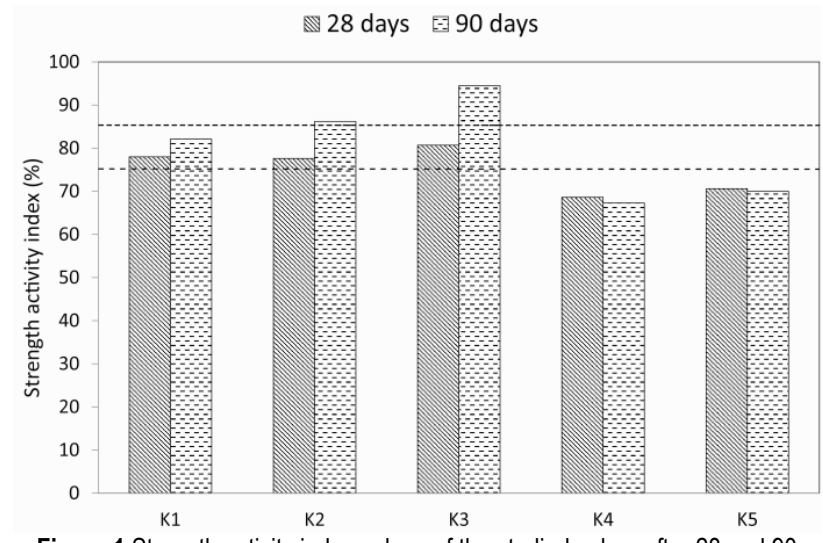

Figure 1 Strength activity index values of the studied ashes after 28 and 90 days

\subsubsection{Frattini Test}

Tab. 3 displays the concentrations determined for $\left[\mathrm{OH}^{-}\right.$ ] and $[\mathrm{CaO}]$ in the sample solutions after 8 and 15 days, together with the calculated theoretical $\mathrm{CaO}$ maximum and $\mathrm{CaO}$ reduction. Fig. 2 compares the measured solution compositions to the portlandite solubility curve.

As can be seen from Fig. 2, all the studied ashes with the exception of $\mathrm{K} 1$ and $\mathrm{K} 5$ presented positive pozzolanicity at 8 days when $20 \%$ CEM I was replaced by ash, according to standard EN 196-5 for pozzolanic cements [23]. The K2, K3 and K4 blends showed a clear pozzolanic reaction, with both $\mathrm{CaO}$ concentration and alkalinity indicating undersaturation with respect to portlandite. In contrast, ashes K1 and K5 did not satisfy the test for pozzolanicity, neither after 8 days nor after 15 days. In the case of ash $\mathrm{K} 4$, whereas the value after 8 days was only slightly below the solubility curve, after 15 days it shifted considerably lower into the pozzolanic area, demonstrating the slow reactivity of this particular ash.

Table 3 Frattini test results for the ashes.

\begin{tabular}{|c|c|c|c|c|c|c|c|c|}
\hline \multirow{3}{*}{ Ash } & \multicolumn{2}{|c|}{$\begin{array}{c}{[\mathrm{OH}]} \\
(\mathrm{mmol} / 1)\end{array}$} & \multicolumn{2}{|c|}{$\begin{array}{c}{[\mathrm{CaO}]} \\
(\mathrm{mmol} / \mathrm{l})\end{array}$} & $\begin{array}{c}\text { Theoretical } \\
\text { max. [CaO] } \\
(\mathrm{mmol} / \mathrm{l})\end{array}$ & \multicolumn{2}{|c|}{$\begin{array}{c}{[\mathrm{CaO}]} \\
\text { reduction (\%) }\end{array}$} \\
\cline { 2 - 10 } & $8 \mathrm{D}$ & $15 \mathrm{D}$ & $8 \mathrm{D}$ & $15 \mathrm{D}$ & $8 \mathrm{D}$ & $15 \mathrm{D}$ & $8 \mathrm{D}$ & $15 \mathrm{D}$ \\
\hline $\mathrm{K} 1$ & 61,2 & 62,4 & 9,8 & 8,8 & 8,6 & 7,4 & - & - \\
\hline $\mathrm{K} 2$ & 57,6 & 58,4 & 7,2 & 5,5 & 8,2 & 8,1 & 11,8 & 31,4 \\
\hline $\mathrm{K} 3$ & 57,9 & 59,5 & 6,8 & 5,4 & 8,2 & 7,9 & 16,8 & 31,5 \\
\hline $\mathrm{K} 4$ & 58,1 & 59,9 & 8,0 & 6,2 & 8,1 & 7,8 & 1,1 & 21,0 \\
\hline $\mathrm{K} 5$ & 62,4 & 58,8 & 10,2 & 9,6 & 7,4 & 8,0 & - & - \\
\hline
\end{tabular}

The values corresponding to the two fly ashes (K2, K3) are located below the saturation curve, indicating the removal of $\mathrm{Ca}^{2+}$ from the solution, which is attributed to pozzolanic activity [22]; clear progress in the pozzolanic reaction is also apparent after 15 days. The majority of the studied ashes follow a reaction pathway shifting to higher alkalinity and lower $\mathrm{Ca}$ ion concentrations below the curve in the pozzolanicity assessment diagram, indicating that increasing alkali input in the aqueous solution reduces the 
solubility of $\mathrm{Ca}$ ions, a process that is characteristic of pozzolans associated with major alkali-calcium-ion exchange [34].

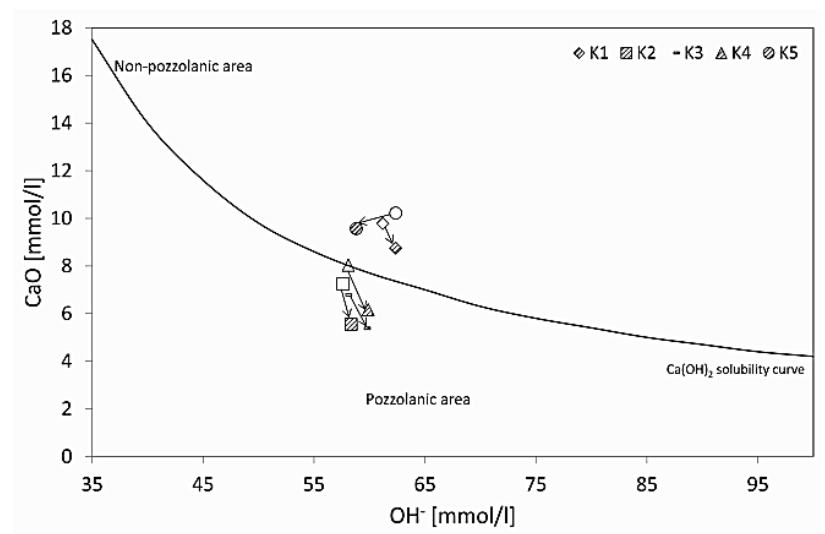

Figure 2 Frattini test results for the five studied ashes after 8 and 15 (hatched) days

Since standard EN 196-5 [23] provides $\mathrm{Ca}(\mathrm{OH})_{2}$ solubility data at $40{ }^{\circ} \mathrm{C}$ when the $\mathrm{OH}^{-}$content is between 35 and $100 \mathrm{mmol} / \mathrm{l}$, for materials within this range the theoretical maximum $[\mathrm{CaO}]$ concentration and $\mathrm{CaO}$ reduction can be calculated (Table 3 ). For those ashes with a calculated theoretical maximum $\mathrm{CaO}$ lower than the measured $\mathrm{CaO}$ (ashes $\mathrm{K} 1$ and $\mathrm{K} 5$ ), it was not possible to calculate $\mathrm{CaO}$ reduction; in both cases the amount of calcium in solution was greater than expected. Analysis of Tab. 3 reveals that in the case of ash $\mathrm{K} 4$, lime removal was enhanced from $1.1 \%$ after 8 days to $21.0 \%$ after 15 days. In contrast, lime removal for both fly ashes K2 and K3 amounted to approx. $31 \%$ after 15 days. The obtained data thus suggest that whereas the pozzolanic activity of ash $\mathrm{K} 4$ is slow, $\mathrm{K} 2$ and $\mathrm{K} 3$ are more reactive. Overall, the trend in ash reactivity as determined by the Frattini test followed the order $\mathrm{K} 3>\mathrm{K} 2>\mathrm{K} 4>\mathrm{K} 1>\mathrm{K} 5$.

Similarly to that observed for the SAI results, the greatest reactivity in the Frattini tests was detected in the two coal fly ashes $\mathrm{K} 2$ and $\mathrm{K} 3$, followed by $\mathrm{K} 4$, a pattern mostly related to the relatively high reactive $\mathrm{SiO}_{2}$ content of these particular ashes. It should be noted that as the test procedure assumes that no other source of soluble calcium is present in the system, any leaching of calcium would invalidate the results [22, 34]. Significantly, all the studied ashes contained quite high amounts of $\mathrm{CaO}$, as shown in Tab. 2. However, although ashes $\mathrm{K} 1$ and $\mathrm{K} 2$ exhibited similar $\mathrm{CaO}$ contents, as well as similar free and reactive $\mathrm{CaO}$ levels, the former is positioned in the non-pozzolanic area and the latter in the pozzolanic area, a discrepancy potentially ascribed to the considerably lower reactive $\mathrm{SiO}_{2}$ content of ash $\mathrm{K} 1$. Ash $\mathrm{K} 4$ contains less free and reactive $\mathrm{CaO}$, but a higher proportion of reactive $\mathrm{SiO}_{2}$ when compared to K1. Finally, the negative pozzolanicity of ash $\mathrm{K} 5$ is likely a reflection of its low reactive $\mathrm{SiO}_{2}$ content on one hand and high $\mathrm{CaO}$ content on the other, including a large proportion of free and reactive $\mathrm{CaO}$.

\subsubsection{DTA/TG Analysis}

Fig. 3 displays consumed calcium hydroxide content plotted vs. curing time for the tested ash/lime pastes, based on the obtained TG data. According to this figure, ashes K1 and K2 were associated with the highest rate of portlandite consumption, indicating the greatest pozzolanic activity. For ash K1, 87\% of the initial amount of portlandite was consumed after 7 days, with this amount subsequently remaining unchanged throughout the experiment. Although the amount of reacted portlandite recorded after 7 days was lower in the case of ash K2, 83\% consumption was observed after 28 days, a value close to that recorded for ash K1. Similarly, although the siliceous fly ash K3 exhibited a slower reaction rate, the total amount of consumed portlandite after 90 days reached those of ashes $\mathrm{K} 2$ and $\mathrm{K} 1$. In contrast, despite the consumption of portlandite for ash $\mathrm{K} 4$ being greater than that recorded for ash K3 after both 7 and 28 days, no subsequent increase was observed, with around $61 \%$ consumption recorded after 90 days. No significant portlandite consumption was observed for the paste containing ash K5, even after 90 days. Overall, the trend in ash reactivity as determined by DTA/TG analysis followed the order $\mathrm{K} 1>\mathrm{K} 2>\mathrm{K} 3>\mathrm{K} 4>\mathrm{K} 5$.

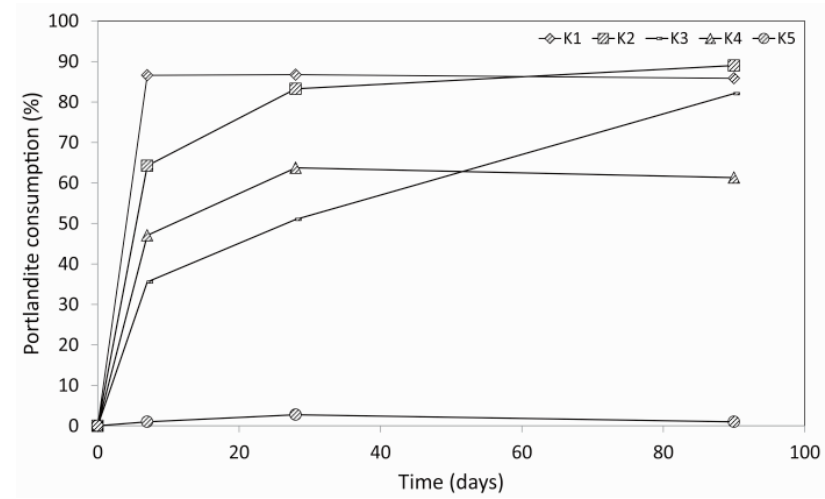

Figure 3 Calcium hydroxide consumption in mixtures containing $30 \%$ calcium hydroxide and $70 \%$ ash

The analysis of reaction kinetics produced similar results to those of the SAI tests, with the highest reactivity recorded for ash $\mathrm{K} 1$ and gradual progress in the pozzolanic reaction for ashes $\mathrm{K} 2$ and $\mathrm{K} 3$. The siliceous fly ash $\mathrm{K} 3$ exhibited the slowest reaction kinetics, which to some extent reflects its low BET specific surface area; this property controls the pozzolanic reaction rate in the short term, with chemistry taking over in the long term $[8,12$, $35,36]$.

Although the DTA/TG results are consistent with those of both the SAI and Frattini tests for ashes K2, K3 and $\mathrm{K} 5$, inconsistencies were recorded for ashes $\mathrm{K} 1$ and K4. According to the SAI and Frattini tests, ash K1 presented insufficient pozzolanic activity, while ash K4 exhibited activity in the Frattini but not the SAI test. However, DTA/TG analyses produced positive results for both ashes, including portlandite consumption after only 7 days. The negative SAI test results for ashes K1 and K4 could be explained by increased water demand due to their high BET surface areas. In order to obtain a standard consistency of lime/ash mixture for DTA/TG analysis, significantly different amounts of water were required for each sample; this is in contrast to the SAI tests, for which $\mathrm{w} / \mathrm{b}$ values were kept constant. This discrepancy may explain why ashes $\mathrm{K} 1$ and $\mathrm{K} 4$ both produced negative SAI results but differed in the Frattini test. Moreover, direct correlation of test results can only be achieved if the cement/ash ratios of the two tests are equal. 
Although many test methods are standardised, not all constituents of the test procedure are precisely specified. For example, the Frattini test provides requirements for the testing of pozzolanic cements blended with SCM in the range of 11-55\% according to standard EN 197-1 [4]. In the present study it was evident that $20 \mathrm{wt} . \%$ of ash K1 was not sufficient; a higher amount of ash in the cement paste would have consumed more portlandite and consequently produced a positive pozzolanic result. A number of important factors, such as cement type, cement replacement level, the presence of a water reducing agent, $\mathrm{w} / \mathrm{b}$ ratio and volumetric proportions clearly influence the performance of a pozzolan when used in mortar or concrete [37, 20, 38]. In addition, some materials are known to possess pozzolanic properties only when their constituent particles are less than $45 \mu \mathrm{m}$ in diameter, with their reactivity proportional to the amount of particles less than $10 \mu \mathrm{m}$ [38]. As most tests are limited to the analysis of compositions recognised as standard, the results obtained refer only to a specific mixture and thus cannot fully confirm whether a material is or is not pozzolanic.

\section{CONCLUSIONS}

In this study, five ashes of various origins were investigated in terms of their mineralogical-chemical, physical and pozzolanic properties, in order to identify their potential for use as SCMs.

The main conclusions to be drawn from this investigation can be summarised as follows:

- The two coal fly ashes K2 (calcareous fly ash) and K3 (siliceous fly ash) were recognized as being pozzolanically active by all three methods, i.e. the SAI and Frattini tests, and DTA/TG analysis. This is mostly due to these ashes' high proportion of the amorphous phase and especially of reactive $\mathrm{SiO}_{2}$, which was the highest among the studied samples. Ash K2 exhibited a higher reaction rate, likely related to its larger BET surface area with respect to that of ash K3.

- In contrast, the paper mill ash K5, which consisted predominantly of bottom ash together with a small amount of fly ash, was recognised as non-active by all three methods, and may thus be considered a nonactive filler rather than an SCM. This ash is characterized by its low amorphous phase and reactive $\mathrm{SiO}_{2}$ content, with larger levels of Ca-based phases. Ash K5 also contained the largest fraction of particles above $45 \mu \mathrm{m}$ diameter among all the studied ashes.

- For the two coal/biomass fly ashes K1 and K4, whereas the SAI and/or Frattini test produced negative results, DTA/TG analysis yielded considerable portlandite consumption. Both of these ashes contained a significantly lower amount of reactive $\mathrm{SiO}_{2}$ and a higher BET surface area than the two coal fly ashes. Thus, the negative SAI results could be explained by the former ashes' high demand for water due to their large BET surface areas, which prevent hydration reactions.

The above findings demonstrate that for the evaluation of pozzolanic properties it is essential to combine several test methods. Whereas the SAI method indicates the direct influence of pozzolanic activity on mechanical properties as the most relevant parameter, the Frattini test and DTA/TG analysis provide a direct insight into the amount of portlandite spent on the formation of hydrates, and thus make possible direct comparison of different pozzolanic materials. However, as yet no criteria have been established based on these two methods (as they have for the SAI test).

\section{Acknowledgements}

The authors acknowledge the financial support from the Slovenian Research Agency (research core funding No. P2-0273). The Metrology Institute of the Republic of Slovenia is acknowledged for the use of XRF.

\section{REFERENCES}

[1] Juenger, M. C. G. \& Siddique, R. (2015). Recent advances in understanding the role of supplementary cementitious materials in concrete. Cement and Concrete Research, 78, 71-80. https://doi.org/10.1016/j.cemconres.2015.03.018

[2] Avet, F., Snellings, R., Alujas Diaz, A., Ben Haha, M., \& Scrivener, K. (2016). Development of a new rapid, relevant and reliable $\left(\mathrm{R}^{3}\right)$ test method to evaluate pozzolanic reactivity of calcined kaolinitic clays. Cement and Concrete Research, 85, 1-11. https://doi.org/10.1016/j.cemconres.2016.02.015

[3] Snellings, R. \& Scrivener K. L. (2016). Rapid screening tests for supplementry cementitious materials: past and future. Materials and Structures, 49, 3265-3279. https://doi.org/10.1617/s11527-015-0718-z

[4] EN 197-1:2011. Cement - Part 1. Composition, specifications and conformity criteria for common cements.

[5] EN 450-1:2012. Fly ash for concrete - Part 1: Definition, specifications and conformity criteria.

[6] Tantawy, M. A., El-Roudi, A. M., Abdalla, E. M., \& Abdelzaher M. A. (2012). Evaluation of the Pozzolanic Activity of Sewage Sludge Ash. ISRN Chemical Engineering Volume, Article ID 487037, 8 pages. https://doi.org/10.5402/2012/487037

[7] Paya, J., Monzó, J., Borrachero, M. V., \& Velázquez, S. (2003). Evaluation of the pozzolanic activity of fluid catalytic cracking catalyst residue (FC3R). Thermogravimetric analysis studies on FC3R-Portland cement pastes. Cement and Concrete Research, 33, 603-609. https://doi.org/10.1016/S0008-8846(02)01026-8

[8] Lea, F. M. (1998). Lea's Chemistry of Cement and Concrete. $4^{\text {rd }}$ Edition. London, Sydney, Auckland, Arnold, New York, Toronto: J. Wiley \& Sons.

[9] Luxán, M. P., Sánchez de Rojas, M. I., \& Frías, M. (1989). Rapid evaluation of pozzolanic activity of natural products by conductivity measurement. Cement and Concrete Research, 19, 69-80. https://doi.org/10.1016/0008-8846(89)90067-7

[10] Cheriaf, M., Cavalcante Rocha, J., \& Péra, J. (1999). Pozzolanic properties of pulverized coal combustion bottom ash. Cement and Concrete Research, 29, 1387-1391. https://doi.org/10.1016/S0008-8846(99)00098-8

[11] Rajamma, R., Ball, R. J., Tarelho, L. A., Allen, G. C., Labrincha, J. A., \& Ferreira, V. M. (2009). Characterisation and use of biomass fly ash in cement-based materials. Journal of Hazardous Materials, 172, 1049-1060. https://doi.org/10.1016/j.jhazmat.2009.07.109

[12] Wang, S. \& Baxter, L. (2007). Comprehensive study of biomass fly ash in concrete: Strength, microscopy, kinetics and durability. Fuel Processing Technology, 88, 1165-1170. https://doi.org/10.1016/j.fuproc.2007.06.016 
[13] Esteves, T. C., Rajamma, R., Soares, D., Silva, A. S. Ferreira, V. M., \& Labrincha, J. A. (2012). Use of biomass fly ash for mitigation of alkali-silica reaction of cement mortars. Construction and Building Materials, 26, 687-693. https://doi.org/10.1016/j.conbuildmat.2011.06.075

[14] Donatello, S., Tyrer, M., \& Cheeseman, C. R. (2010). Comparison of test methods to assess pozzolanic activity. Cement and Concrete Composites, 32, 121-127. https://doi.org/10.1016/j.cemconcomp.2009.10.008

[15] McCarter, W. J. \& Tran, D. (1996). Electrical Impedance Characterization of Cement-Based Materials. Construction and Building Materials, 108, 179-184. https://doi.org/10.1016/0950-0618(95)00089-5

[16] Mostafa, N. Y., El-Hemaly, S. A. S., Al-Wakeel, E. I., \& Brown, P. W. (2001). Characterization and evaluation the pozzolanic activity of Egyptian industrial by-products: Isilica fume and dealuminated kaolin. Cement and Concrete Research, 31, 467-474. https://doi.org/10.1016/S0008-8846(00)00485-3

[17] Moropoulou, A., Bakolas, A., \& Aggalakopoulou, E. (2004). Evaluation of Pozzolanic Activity of Natural and Artificial Pozzolans by Thermal Analysis. Thermochimica Acta, 420, 135-140. https://doi.org/10.1016/j.tca.2003.11.059

[18] Parhizkar, T., Najimi, M., Pourkhorshidi, A. R., Jafarpour, F., Hillemeier, B., Herr, R., \& Transaction, A. (2010). Proposing a new approach for qualification of natural pozzolans. Transaction A: Civil Engineering, 17, 450-456.

[19] Velázquez, S., Monzó, J. M., Borrachero, M. V., \& Payá, J. (2014). Assessment of Pozzolanic Activity Using Methods Based on the Measurement of Electrical Conductivity of Suspensions of Portland Cement and Pozzolan. Materials, 7 , 7533-7547. https://doi.org/10.3390/ma7117533

[20] Massazza, F. (1998). Pozzolana and pozzolanic cements. In: Hewlett, P. C., editor. Lea's Chemistry of Cement and Concrete. $4^{\text {th }}$ Edition, 471-635. https://doi.org/10.1016/B978-075066256-7/50022-9

[21] Torres Agredo, R., Mejía de Gutiérrez, C., Escandón Giraldo, E., \& González Salcedo, L. O. (2014). Characterization of sugar cane bagasse ash as supplementary material for Portland cement. Ingeniería e investigación, 34, 5-10. https://doi.org/10.15446/ing.investig.v34n1.42787

[22] Donatello, S., Tyrer, M., \& Cheeseman, C. R. (2010). Comparison of test methods to assess pozzolanic activity. Cement and Concrete Composites, 32, 121-127. https://doi.org/10.1016/j.cemconcomp.2009.10.008

[23] EN 196-5:2011: Methods of testing cement - Part 5: Pozzolanicity test for pozzolanic cement.

[24] Pacewska, B., Blonkowski. G., \& Wilińska, I. (2008). Studies on the pozzolanic and hydraulic properties of fly ashes in model systems. Journal of Thermal Analysis and Calorimetry, 294, 469-476. https://doi.org/10.1007/s10973-008-9179-8

[25] Roszczynialski, W. J. (2002). Determination of pozzolanic activity of materials by thermal analysis. Journal of Thermal Analysis and Calorimetry, 70, 387-392. https://doi.org/10.1023/A:1021660020674

[26] Ubbriaco, P. \& Tasselli, F. (1998). A study of the hydration of lime-pozzolan binders. Journal of Thermal Analysis and Calorimetry, 52, 1047-1054. https://doi.org/10.1023/A:1010101126587

[27] Amer, A. A. (1998). Thermal analysis of hydrated fly ashlime pastes. Journal of Thermal Analysis and Calorimetry, 54, 837-843. https://doi.org/10.1023/A:1010100222075

[28] EN 196-2:2013: Method of testing cement - Part 2: Chemical analysis of cement.

[29] EN 451-1:2003. Method of testing fly ash -Part 1: Determination of free calcium oxide content.

[30] EN 451-2:1994 Method of testing fly ash - Part 2: Determination of fineness by wet sieving.
[31] EN 196-1:2005. Methods of testing cement - Part 1: Determination of strength.

[32] Siddique, R. \& Iqbal Khan, M. (2011). Supplementary Cementing Materials. Heidelberg, Dortrecht, London, New York: Springer. https://doi.org/10.1007/978-3-642-17866-5

[33] Walker, R. \& Pavia, S. (2011). Physical properties and reactivity of pozzolans, and their influence on the properties of lime-pozzolan pastes. Materials and Structures, 44, 11391150. https://doi.org/10.1617/s11527-010-9689-2

[34] Pourkhorshidi, A. R., Najimi, M., Parhizkar, T., Hillemeier, B., \& Herr, R. (2010). A comparative study of the evaluation methods for pozzolans. Advances in Cement Research, 22, 157-164. https://doi.org/10.1680/adcr.2010.22.3.157

[35] Mertens, G., Snellings, R., Van Balen, K., Bicer-Imsir, B., Verlooy, P., \& Elsen, J. (2009). Pozzolanic reactions of common natural zeolites with lime and parameters affecting their reactivity. Cement and Concrete Research, 39, 233240. https://doi.org/10.1016/j.cemconres.2008.11.008

[36] Tironi, A., Trezza, M. A., Scian, A. N., \& Irassar, E. F. (2014). Thermal analysis to assess pozzolanic activity of calcined kaolinitic clays. Journal of Thermal Analysis and Calorimetry, 117, 547-556. https://doi.org/10.1007/s10973-014-3816-1

[37] Gava, G. P. \& Prudêncio, L. R. (2007). Pozzolanic activity tests as a measure of pozzolans' performance. Part 1 . Magazine of Concrete Research, 59, 729-734. https://doi.org/10.1680/macr.2007.59.10.729

[38] Bentz, D. P., Durán-Herrera, A., \& Galvez-Moreno, D. (2011). Comparison of ASTM C311 Strenght Acivity Index Testing vs. Testing Based on Constant Volumetric Proportions. Journal of ASTM International, 9, 7 pp.

Contact information:

Sabina KRAMAR, doc. dr

(Corresponding author)

Slovenian National Building and Civil Engineering Institute,

Dimičeva Ulica 12, 1000, Ljubljana, Slovenia

E-mail: sabina.kramar@zag.si

Vilma DUCMAN, dr

Slovenian National Building and Civil Engineering Institute

Dimičeva Ulica 12, 1000, Ljubljana, Slovenia

E-mail: vilma.ducman@zag.si 